УДК 159.9:37.07:005.95]:613.86

DOI https://doi.org/10.26661/2310-4368/2021-3-4

\title{
ЕМПІРИЧНЕ ДОСЛІДЖЕННЯ ВПЛИВУ САМОЕФЕКТИВНОСТІ НА ПСИХОЛОГІЧНЕ ЗДОРОВ'Я ОСВІТНЬОГО ПЕРСОНАЛУ В УМОВАХ СОЦІАЛЬНОЇ НАПРУЖЕНОСТІ
}

\author{
Креденцер О. В. \\ доктор психологічних наук, дочент, \\ провідний науковий співробітник лабораторії організаційної психологї \\ Інститут психології імені $Г$. С. Костюка \\ Національної академії педагогічних наук України \\ вул. Паньківська, 2, Київ, Україна \\ orcid.org/0000-0003-4119-190X \\ okred278@gmail.com
}

\begin{abstract}
Ключові слова:
самоефективність, психологічне здоров'я, освітні організації, персонал освітніх організачій, сочіальна напруженість.
\end{abstract}

У статті представлено результати емпіричного дослідження впливу самоефективності на психологічне здоров'я освітнього персоналу в умовах соціальної напруженості. Визначено самоефективність, як систему суб' єктивних уявлень про здатність успішно діяти в конкретних ситуаціях, яка має оцінюючий характер і забезпечує регуляцію дій, спрямованих на досягнення певних цілей, за рахунок формування суджень про свою здатність успішно вирішити поставлені завдання. Визначено недостатній рівень розвитку самоефективності у персоналу освітніх організацій. В основу дослідження психологічного здоров'я персоналу освітніх організацій покладено підхід, розроблений в лабораторії організаційної та соціальної психології Інституту психології імені Г.С. Костюка НАПН України. Згідно даного підходу структура психологічного здоров'я визначається, як система трьох компонентів: 1) когнітивно-емоційний компонент визначається за допомоги показника «ставлення до психологічного здоров'я»; 2) рефлексивно-особистісний, який досліджується через показник «позитивне психічне здоров'я»; 3) операційно-функціональний, який включає показники «локусу контролю здоров’я» («внутрішній контроль», «контроль «могутніми іншими», «контроль випадку»). Доведено, що психологічне здоров’я тісно пов'язано з самоефективністю персоналу освітніх організацій. Особливо це стосується рефлексивно-особистісного компоненту, за яким визначено прямий статистично значущий зв'язок зі всіма видами самоефективності. Встановлено, що локус контролю здоров’я за шкалою «контроль випадку» негативно пов'язаний з усіма видами самоефективності, тобто освітяни, які мають високий рівень розвитку самоефективності, не покладаються на зовнішні обставини у питаннях, пов'язаних із забезпеченням їх здоров'я. Зазначено, що чим вищий рівень переконаності освітян у своїх власних можливостях, у тому що вони можуть здійснювати ефективно свою роботу, тим вищий рівень вираженості позитивного психічного здоров'я та менший рівень переконаності в тому, що здоров'я залежить від випадку, везіння або долі. 


\title{
EMPIRICAL STUDY OF THE IMPACT OF EDUCATIONAL STAFF'S SELF-EFFICIENCY ON THEIR PSYCHOLOGICAL HEALTH IN CONDITIONS OF SOCIAL TENSION
}

\author{
Kredentser O. V. \\ PsyD, Associate Professor, \\ Leading Researcher at the Laboratory of Organizational Psychology \\ National Academy of Pedagogical Sciences of Ukraine \\ G. S. Kostiyk Institute of Psychology \\ Pankivska str., 2, Kyiv, Ukraine \\ orcid.org/0000-0003-4119-190X \\ okred278@gmail.com
}

Key words: self-efficacy, psychological health, educational organizations, educational staff, social tension.
The article presents the results of an empirical study of the impact of educational staff's self-efficacy on their psychological health in conditions of social tension. Self-efficacy is defined as a system of individuals' ideas about their ability to be successful in specific situations that evaluates and regulates individuals' actions aimed at achieving certain goals by forming judgments about their ability to successfully solve problems. The author has found that educational organization staff have low self-efficacy. The study of educational staff's psychological health conducted by the author used the approach developed in the laboratory of organizational and social psychology of the G.S. Kostiuk Institute of Psychology of the NAES of Ukraine, according to which psychological health is made up of (1) a cognitiveemotional component ("attitude to psychological health" indicator), (2) a reflexive-personal component ("positive mental health" indicator), and (3) an operational-functional component (which includes the indicators of the "locus of health control": internal control, control by powerful others, and case control). Educational staff's psychological health was shown to be closely linked to their self-efficacy. This is especially true of the reflexive-personal component, which determines a direct statistically significant relationship with all types of self-efficacy. It has been shown that the locus of health control on the "case control" scale negatively associates with all types of self-efficacy, i.e. the educational staff who have high self-efficacy do not rely on external circumstances in matters related to their health. It is noted that the higher the level of educational staff's conviction of their own abilities and their work effectiveness, the better their positive psychological health and the weaker their belief that health depends on chance, luck or fate.
Постановка проблеми. Важливим та актуальним завданням сьогодення для науковців-психологів $\epsilon$ пошук дієвих чинників, що сприяють підвищенню ефективності діяльності персоналу освітніх організацій в умовах соціальної напруженості та забезпечують його психологічне здоров'я.

Аналіз літератури (Н. Водоп'янова, А. Густелева [5], А. Кузнецова, В. Никишина [10], D. Barni, F. Danioni, P. Benevene [21], C. Guarnaccia, F. Scrima, A. Civilleri, L. Salerno [22]; R. Gumbau, J. Peiro, M. Salanova [23], A. Fabio, L. Palazzeschi [24], T.A. Judge, J.E. Bono [25], R. Lent, G. Hackett [27] та наші попередні розробки [11; 12] показали, що одним із таких чинників виступає самоефективність особистості.

Концепція самоефективності вперше була запропонована А. Бандуроюще в кінці 1970-х років i активно досліджувалася ним протягом двадцяти років. А. Бандура [20] вважає, що привабливість результату i віра в позитивний результат недостатні для запуску мотивації суб'єкта. Необхідна також віра в свої здібності впоратися 3 даним видом діяльності. Самоефективність полягає в тому, наскільки компетентною почувається людина, виконуючи ту чи іншу справу. А. Бандура вважає, що самоефективність - центральна і найважливіша детермінанта людської поведінки. 
Згідно $з$ даними, отриманими А. Бандурою і його колегами, люди 3 високою самоефективністю більш наполегливі, краще вчяться, а також володіють великою самоповагою, менш тривожні і менш схильні до депресій.

Отже, ми грунтуючись на підходах ряду авторів $[6 ; 7 ; 11 ; 20 ; 25]$, ми визначаємо самоефективнicmb, як систему суб'єктивних уявлень про здатність успішно діяти в конкретних ситуаціях, яка має оцінюючий характер і забезпечує регуляцію дій, спрямованих на досягнення певних цілей, за рахунок формування суджень про свою здатність успішно вирішити поставлені завдання.

Останніми роками проблема самоефективності стала досить інтенсивно досліджуватись українськими психологами. Зокрема, розглядаються загальні проблеми самоефективності особистості (Т. Гальцева [7], В. Михайличенко, Н. Полякова [14], Д. Шапошник [19] та ін.), самоефективність студентів різних спеціальностей у контексті їх професійного становлення (О. Вовк [4], М. Гайдар [6], О. Музика [15], I. Сняданко [17] та ін.), самоефективність у процесі професійної діяльності фахівців різних професійних категорій (О. Бондарчук [2], Н. Пророк [16]), підприємницька самоефективність (I. Абдуллаєва [11], О. Креденцер [12] та ін.).

Окрім того, досить широкого розповсюдження проблема самоефективності набула і в організаційній психології. Тут можна назвати наступні напрямки досліджень.

По-перше, показаний зв'язок самоефективності персоналу комерційних організацій та ефективності роботи та задоволеністю роботою (A. Stajkovic, F. Luthans [30], T. Judge, J. Bono [25]; C. Guarnaccia, F. Scrima, A. Civilleri, L. Salerno [22]; B. Schyns, G. von Collani [31] та ін.).

Так, C. Guarnaccia, F. Scrima, A. Civilleri, L. Salerno [22] в своєму дослідженні працівників приватних та державних організацій показали, що професійна самоефективність опосередковує взаємозв'язок між незабезпеченою роботою, залученням до роботи, задоволеністю роботою та здоров'ям працівників. Дослідники довели вплив незахищеності роботою на залучення, задоволення та здоров'я працівників та показали медіаційну роль професійної самоефективності. Автори наголошують, що в часи економічної кризи, коли неможливо гарантувати постійні контракти, менеджери з персоналу можуть розглядати професійну самоефективність як суттєвий психологічний peсурс. На нашу думку, результати цього дослідження цілком екстраполюються і на напружені умови сьогодення, зокрема, всесвітньої пандемії.

В дослідженні T. Judge, J. Bono [25] представлені результати взаємозв' язку 4 особистісних рис (самооцінки, самоефективності, локусу контр- олю та емоційної стабільності) із задоволенням роботою та іiі ефективністю. Отримані результати показують наявність потужних зав'язків між всіма показниками, на основі чого автори роблять припущення, що ці риси є одними 3 найкращих прогностичних показників задоволення роботою та її ефективністю.

По-друге, досліджувався зв'язок самоефективності персоналу організацій 3 його різних соціально-психологічних характеристик: медіаторний вплив самоефективності у зв'язку з особистісними характеристиками персоналу та кар'єрними орієнтаціями (M. Nauta [29]); зв'язок емоційного інтелекту та самоефективності вчителів (A. Fabio, L. Palazzeschi [24]), зв'язок самоефективності вчителів та їх цінностей та професійної мотивації (D. Barni, F. Danioni, P. Benevene [21]).

Так, D. Barni, F. Danioni, P. Benevene [21] у своєму дослідженні показали, що вчителі, для яких такі цінності, як новизна, свобода та вибір власних цілей важливі для сприйняття своєї ефективності, насправді почуваються ефективнішими у своїй педагогічній діяльності, коли відчувають незалежність від зовнішніх умов. І навпаки, в тих школах, де $\epsilon$ потужний зовнішній тиск на діяльність вчителів, там в більшій мірі вчителі надають значення відкритості до змін, і тим більше вони сприймають себе як неефективні.

Отже, аналіз літератури показує, що проблема самоефективності досліджувалась в організаціях різних соціально-економічних сфер, зокрема, в освітніх організаціях, у тому числі, активно досліджується «самоефективність вчителя» (Teacher Self-Efficacy) (A. Fabio, L. Palazzeschi [24]; M. Mo Ching Mok, P. Moore [28]; D. Barni, F. Danioni, P. Benevene [21]).

Вітчизняними вченими також досліджувалась проблема самоефективності персоналу освітніх організацій, зокрема, аналізувались особливості організаційної культури освітніх організацій залежно від самоефективності керівників (О. Бондарчук [2]), особливості самоефективності керівників закладів професійно-технічної освіти як психологічного чинника успішності їхньої професійної діяльності (С. Казакова [13]), підприємницька самоефективність персоналу освітніх організацій як чинник розвитку їх підприємницької активності та задоволеності працею (О. Креденцер [12]), самоефективність та задоволеність професійною діяльністю викладачів університетів (А. Кузнєцова, В. Нікішина [10]) та ін.

У цілому, в рамках когнітивної моделі здоров'яорієнтованої поведінки А. Бандури самоефективність розглядається як детермінанта здоров'яорієнтованої поведінки [20].

Т.М. Титаренко [18], розглядаючи критерії відновлення психологічного здоров'я людини після 
тривалої травматизації, підкреслює, що в цей період ентузіазму відчутно меншає, креативні задуми майже не виникають, а якщо і пробуджуються, то реалізувати їх людина навіть не намагається, бо немає ані сил, ані впевненості у собі, ані віри в те, що це має хоч якісь перспективи. Таким чином, авторка виділяє один із критеріїв відновлення психологічного здоров'я - це можливість підтримання продуктивності і самоефективності особистості, оновлення здатності до самореалізації, підвищення креативності у ставленні до власного життя. Окрім того, Т. Титаренко говорить про те, що важливим для відновлення психологічного здоров'я $\epsilon$ можливість оновлення власної цілісності і безперервності через реконструкцію каузального зв'язку минулого, теперішнього i майбутнього і вибудову нових життєвих перспектив, це відбудова віри у себе, без якої неможлива ефективна самопідтримка і самодопомога [18].

Отже, підсумовуючи, слід зазначити, що проблема самоефективності в контексті забезпечення психологічного здоров'я $є$ актуальним питанням. Разом $з$ тим, воно залишається не дослідженим у вітчизняній психології, зокрема, щодо персоналу освітніх організацій. Виходячи 3 актуальності та недостатньої розробленості проблеми, метою дослідження $\epsilon$ аналіз самоефективності, як детермінанти психологічного здоров’я персоналу освітніх організацій.

Виклад основного матеріалу дослідження.

В основу дослідження психологічного здоров'я персоналу освітніх організацій покладено підхід, розроблений в лабораторії організаційної та соціальної психології Інституту психології імені Г.С. Костюка НАПН України [9]. Згідно даного підходу структура психологічного здоров'я визначається, як система трьох компонентів: 1) когнітивно-емоиійний компонент визначається за допомоги показника «ставлення до психологічного здоров'я»; 2) рефлексивно-особистісний, який досліджується через показник «позитивне психічне здоров'я»; 3) операційно-функиіональний, який включає показники «локусу контролю здоров'я» («внутрішній контроль», «контроль «могутніми іншими», «контроль випадку») [9].

\section{Методи та організація досліджсеня.}

Для проведення дослідження буди використані наступні методики: 1) «Тест визначення рівня самоефективності» (Дж. Маддукс, М. Шеер, модифікація Л. Бояринцевой, під керівництвом Р. Кричевського) [3] (для вимірювання самоефективності); 2) «Шкала ставлення до психологічного здоров’я» (ШСПЗ) (Т.В. Галкіна, Н.Г. Артемцева) [1] (для вимірювання когнітивно-емоційного компонента психологічного здоров'я); 3) «Шкала позитивного психічного здоров'я» (Positive Mental Health Scale (PMH-scale) (J. Lukat, J. Mar- graf, R. Lutz, W.M. van der Veld, E.S. Becker) [26]. (для дослідження рефлексивно-особистісного компонента психологічного здоров'я); 4) «Опитувальник для вимірювання локус контролю здоров'я» (Multidimensional Health Locus-of-Control Scales) [8] (для діагностики операційно-функціонального компонента); 5) анкета-паспортичка.

Обробка результатів здійснювалась методами математичної статистики (описові статистики, кореляційний аналіз, дисперсійний аналіз (ANOVA)) за допомогою програми SPSS (22 версія).

Дослідження проводилось в березні-червні 2020 року серед 473 працівників закладів загальної середньої освіти з різних регіонів України.

Дослідження проведено в рамках виконання науково-дослідної теми лабораторії організаційної та соціальної психології Інституту психології імені Г.С. Костюка НАПН України «Психолого-організаційні детермінанти забезпечення психологічного здоров'я персоналу освітніх організацій в умовах соціальної напруженості» (2019-2021 рр.), науковий керівник -дійсний член НАПН України, доктор психологічних наук, професор Л. Карамушка.

Насамперед розпочнемо 3 аналізу рівня розвитку предметної, соціальної та загальної самоефективності персоналу освітніх організацій.

Як свідчать отримані дані, самоефективність в предметній сфері відповідає рівню значно нижче середнього ( $\mathrm{M}=19,19, \mathrm{SD}=30,37)$, самоефективність у сфері міжособистісного спілкування та загальна самоефективність знаходиться на середньому рівні $(\mathrm{M}=3,12, \mathrm{SD}=8,25)$ та $(\mathrm{M}=22,19$, $\mathrm{SD}=34,72)$ відповідно.

Отже, на наш погляд, на основі отриманих даних ми можемо констатувати, що у освітян спостерігається досить низький рівень переконань в тому, що їх власні компетенції й набутий раніше досвід у педагогічній діяльності вони зможуть застосовувати в аналогічній діяльності в майбутньому, досягнувши при цьому успіху. Нижчий рівень спостерігається у освітян щодо оцінки їх уявлення про власну комунікативну компетентність у поєднанні з упевненістю, що відповідні компетенції вони зможуть успішно застосовувати в ситуації взаємодії з людьми. Тобто ми можемо говорити про недостатній рівень розвитку загальної самоефективності у персоналу освітніх організацій.

Далі проаналізуємо дані, що стосується впливу самоефективності на рівень вираженості компонентів психологічного здоров'я персоналу освітніх організацій в умовах соціальної напруженості.

Розпочнемо 3 аналізу кореляційних зав'язків між самоефективністю у предметній сфері та компонентами психологічного здоров'я персоналу освітніх організацій (таблиця 1). 
Таблиця 1

Зв'язок між самоефективністю та рівнем вираженості компонентів психологічного здоров'я персоналу освітніх організацій (r)

\begin{tabular}{|l|c|c|c|}
\hline $\begin{array}{c}\text { Компоненти психологічного } \\
\text { здоров'я }\end{array}$ & $\begin{array}{c}\text { Самоефективність } \\
\text { у предметній сфері }\end{array}$ & $\begin{array}{c}\text { Самоефективність } \\
\text { сфері міжособистісного } \\
\text { спілкування }\end{array}$ & $\begin{array}{c}\text { Загальна } \\
\text { самоефективність }\end{array}$ \\
\hline Когнітивно-емоційний & 0,078 & $0,095^{*}$ & 0,090 \\
\hline Рефлексивно-особистісний & $0,127^{* *}$ & $0,176^{* * *}$ & $0,149^{* *}$ \\
\hline Операційно-функціональний: & \multicolumn{3}{|l|}{0,017} \\
\hline а) «внутрішній контроль» & 0,034 & $-0,030$ & 0,065 \\
\hline $\begin{array}{l}\text { б) «контроль «могутніми } \\
\text { іншими» }\end{array}$ & 0,066 & 0,059 & $-0,169^{* * *}$ \\
\hline в)«контроль випадку» & $-0,158^{* *}$ & $-0,171^{* * *}$ & 0 \\
\hline
\end{tabular}

Кореляційний аналіз показав, що існує прямий статистично значущий зв'язок між самоефективністю у предметній сфері та рефлексивно-особистісним компонентом психологічного здоров'я $(\mathrm{r}=0,127 ; \mathrm{p}<0,01)$ та обернений зв'язок 3 операційно-функціональним («контроль випадку») компонентом психологічного здоров'я $(\mathrm{r}=-0,158$; $\mathrm{p}<0,01)$.

Результати дисперсійного аналізу (ANOVA) (рис. 1) також показали, що рівень розвитку самоефективності у предметній сфері впливає на рівень вираженості компонентів психологічного здоров'я освітнього персоналу: рефлексивно-особистісного $(\mathrm{p}<0,001)$, та операційно-функціонального («контроль випадку») $(\mathrm{p}<0,001)$.

Наявність такого зв'язку свідчить про те, що чим більше у освітян розвинутий рівень переконань в тому, що їх власні компетенції й набутий

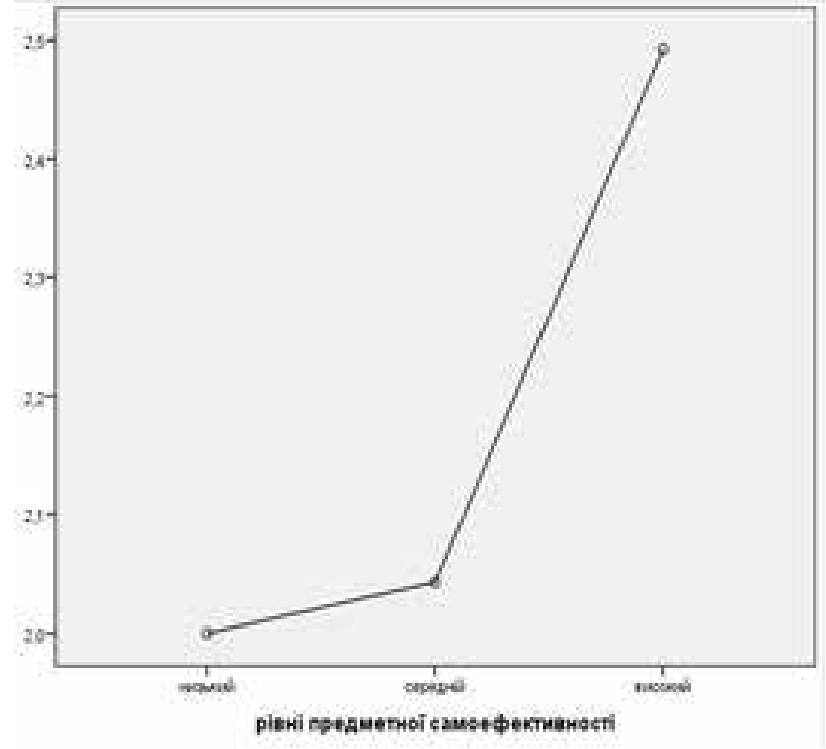

A) досвід у педагогічній діяльності вони зможуть застосовувати в аналогічній діяльності в майбутньому, досягнувши при цьому успіху, тим вище рівень вираженості рефлексивно-особистісного компоненту, тобто позитивного здоров'я та тим менш вони переконані в тому, що здоров'я залежить від випадку, везіння або долі.

Що стосується самоефективності у сфері міжособистісного спілкування, то дані таблиці 1 свідчать про те, що існує прямий статистично значущий зв'язок між самоефективністю у сфері міжособистісного спілкування та такими компонентами психологічного здоров'я, як когнітивно-емоційний $(\mathrm{r}=0,095 ; \mathrm{p}<0,05)$, рефлексивно-особистісний $(\mathrm{r}=0,176 ; \mathrm{p}<0,001)$, а також обернений статистично значущий зв'язок з операційно-функціональним компонентом («контроль випадку») $(\mathrm{r}=-0,171 ; \mathrm{p}<0,001)$.

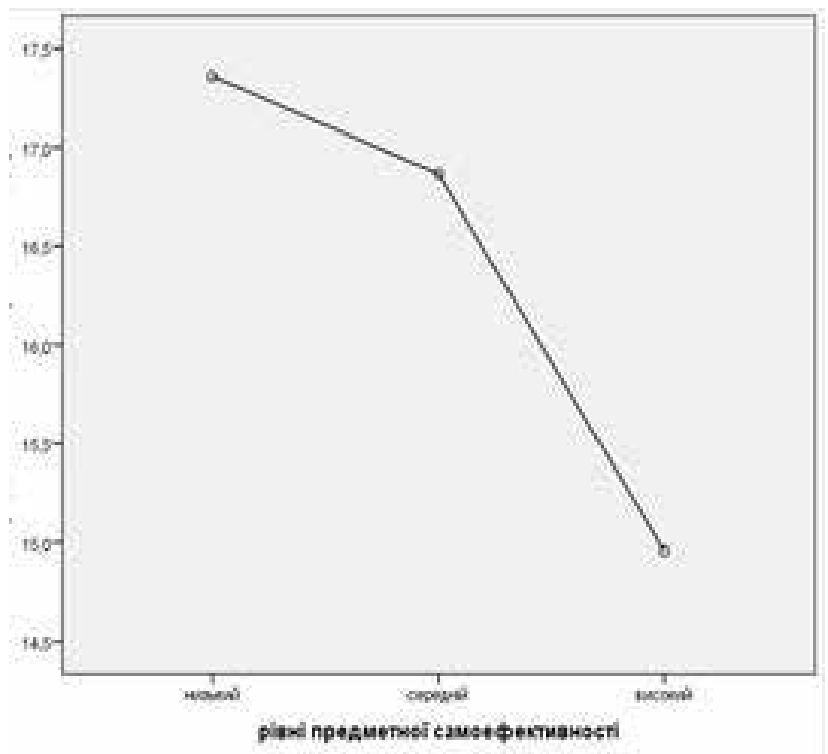

Б)

Рис. 1. Вплив самоефективності у предметній сфері на компоненти психологічного здоров'я персоналу освітніх організацій: рефлексивно-особистісний (А); операційно-функціональний («контроль випадку») (Б) 


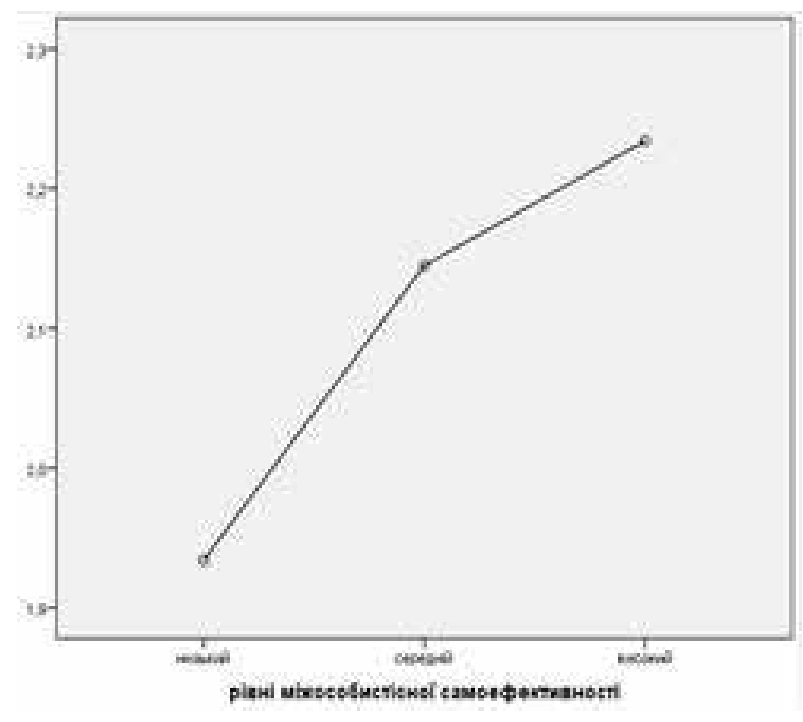

A)

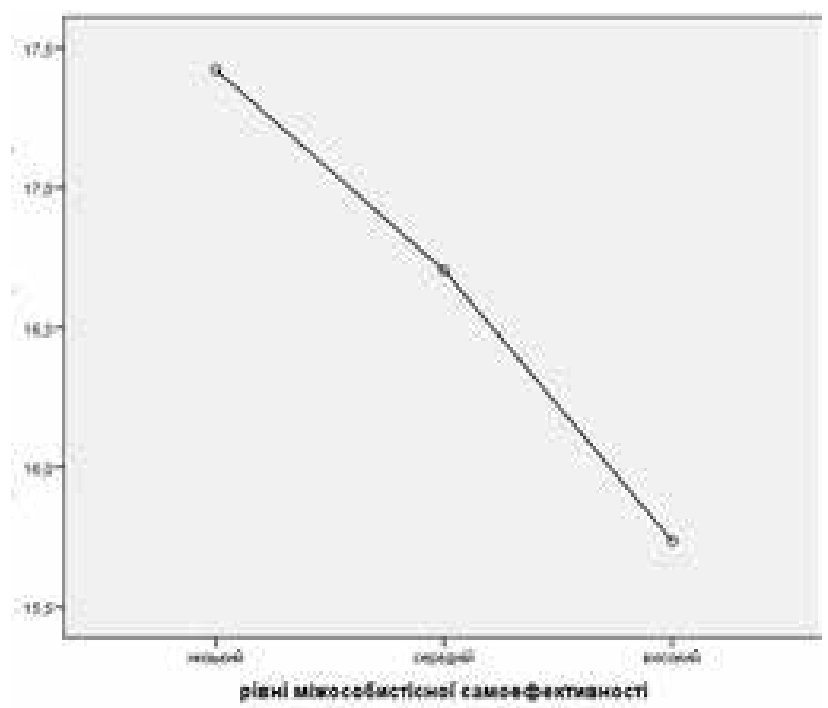

Б)

Рис. 2. Вплив самоефективності у сфері міжособистісного спілкування на компоненти психологічного здоров'я персоналу освітніх організацій: рефлексивно-особистісний (А); операційно-функціональний («контроль випадку») (Б)

Вплив цього виду самоефективності на всі компоненти психологічного здоров'я підтвердився також і результатами дисперсійного аналізу (ANOVA). Згідно даних, зображених на рисунку 2, самоефективність у сфері міжособистісного спілкування впливає на рівень вираженості рефлексивно-особистісного $(\mathrm{p}<0,05)$ та операційно-функціонального («контроль випадку») $(\mathrm{p}<0,05)$ компонентів психологічного здоров'я.

Тобто на основі отриманих результатів ми можемо говорити про те, що рівень переконаності персоналу освітніх організацій в тому, що вони можуть свої відповідні компетенції успішно застосовувати в ситуації взаємодії 3 людьми, позитивно впливає на рівень вираженості когнітивно-емоційного компоненту (ставлення до здоров'я), на рефлексивно-особистісний компонент (позитивне психічне здоров'я) та негативно - на рівень вираженості операційно-функціонального компоненту (шкала «контроль випадку»), тобто тим менш вони переконані в тому, що здоров'я залежить від випадку, везіння або долі.

Подібна ситуація спостерігається i щодо впливу загальної самоефективності персоналу освітніх організацій на компоненти психологічного здоров'я. Дані таблиці 1 свідчать про те, що існує прямий статистично значущий зв'язок між загальною самоефективністю та рефлексивно-особистісним компонентом психологічного здоров'я $(\mathrm{r}=0,149 ; \mathrm{p}<0,01)$ та обернений зв'язок 3 операційно-функціональним («контроль випадку») компонентом психологічного здоров'я $(\mathrm{r}=-0,169 ; \mathrm{p}<0,001)$. Вказаний вплив також під- тверджується і даними дисперсійного аналізу (ANOVA). Загальна самоефективність впливає на рівень вираженості -рефлексивно-особистісного $(\mathrm{p}<0,001)$ та операційно-функціонального («контроль випадку») $(\mathrm{p}<0,001)$ компонентів психологічного здоров'я (рис. 3 ).

Отже, підсумовуючи результати дослідження щодо загальної самоефективності в цілому, зазначимо, що чим вищий рівень переконаності освітян у своїх власних можливостях, у тому що вони можуть здійснювати ефективно свою роботу, тим вищий рівень вираженості позитивного психічного здоров'я та менший рівень переконаності в тому, що здоров'я залежить від випадку, везіння або долі.

Таким чином, проведене емпіричне дослідження довело, що самоефективність $є$ важливою детермінантою психологічного здоров'я персоналу освітніх організацій.

\section{Висновки}

1. Самоефективність - це система суб'єктивних уявлень про здатність успішно діяти в конкретних ситуаціях, яка має оцінюючий характер і забезпечує регуляцію дій, спрямованих на досягнення певних цілей, за рахунок формування суджень про свою здатність успішно вирішити поставлені завдання.

2. Визначено недостатній рівень розвитку самоефективності у персоналу освітніх організацій.

3. Доведено, що психологічне здоров'я тісно пов' язано з самоефективністю персоналу освітніх організацій. Особливо це стосується рефлексивно-особистісного компоненту, за яким визначено 


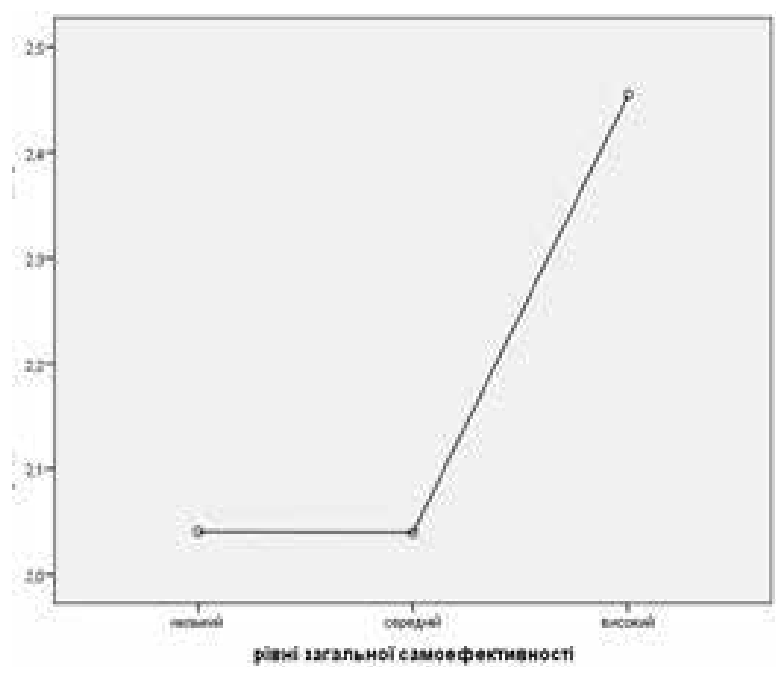

A)

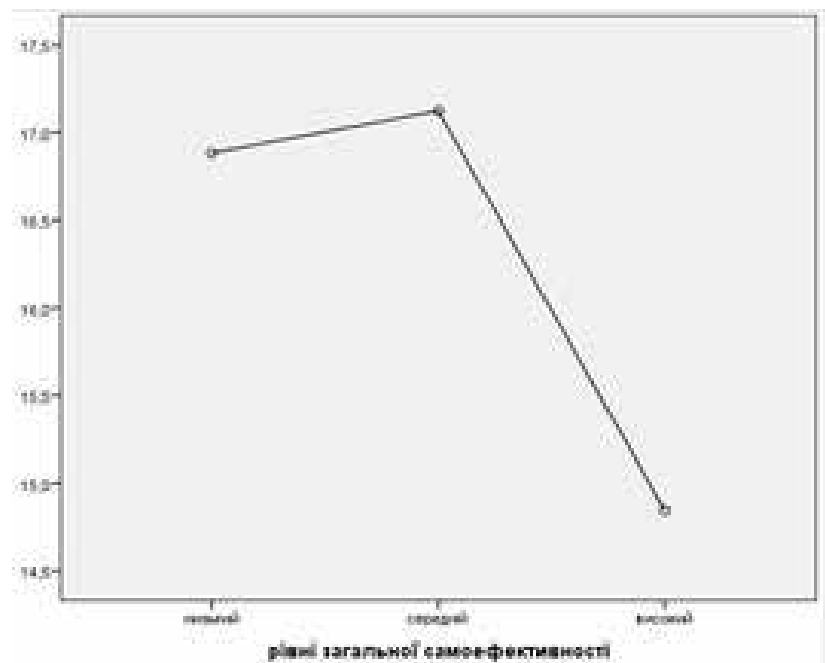

Б)

Рис. 3. Вплив загальної самоефективності на компоненти психологічного здоров'я персоналу освітніх організацій: рефлексивно-особистісний (А); операційно-функціональний («контроль випадку») (Б)

прямий статистично значущий зв'язок зі всіма видами самоефективності.

4. Встановлено, що локус контролю здоров'я за шкалою «контроль випадку» негативно пов'язаний
3 усіма видами самоефективності, тобто освітяни, які мають високий рівень розвитку самоефективності, не покладаються на зовнішні обставини у питаннях, пов'язаних із забезпеченням їх здоров’я.

\section{ЛІТЕРАТУРА}

1. Артемцева Н.Г., Галкина Т.В. Взаимосвязь между отношением к психологическому здоровью и самооценкой личности. Психология человека как субъекта познания, общения и деятельности / отв. ред. В.В. Знаков, А.Л. Журавлев. Москва : Изд-во «Институт психологии РАН», 2018. С. 457-466.

2. Бондарчук O.I. Особливості організаційної культури освітніх організацій залежно від самоефективності керівників. Актуальні проблеми психології. 2014. № 1(41). С. 13-19.

3. Бояринцева А.В.Мотивационно-когнитивные характеристики личности молодого предпринимателя: дис. ... канд. психол. наук: 19.00.01. М., 1995. 249 с.

4. Вовк О.М. Самоефективність: сутність, структура та особливості розвитку в студентському віці. Вісник психологї̈ і соиіальної педагогіки : зб. наук. праць. 2010. № 3. URL: www.psyh.kiev.ua

5. Водоп'янова Н., Густелева А. Воспринимаемая самоэффективность и ресурсообеспеченность как факторы, препятствующие профессиональному выгоранию. Вестник ТвГУ. Серия «Педагогика и психология». 2013. Вып. 4. С. 23-30.

6. Гайдар М.И. Развитие личностной самоэффективности студентов-психологов на этапе вузовского обучения : дисс. ... канд. психол. наук : 19.00.07. Воронеж, 2008. 260 с.

7. Гальцева Т.О. Види самоефективності особистості: їх характеристика та дослідження. Науковий вісник Херсонського державного університету. Серія : психологічні науки. Вип. 4. Херсон, 2015. С. 110-114.

8. Гринберг Дж. Управление стрессом. [7-е изд.] СПб. : Питер, 2002. 496 с.

9. Карамушка Л.М., Креденцер О.В., Терещенко К.В., Лагодзінська В.І., Ковальчук О.С., Івкін В.М. Емпіричне дослідження структурних компонентів психологічного здоров'я персоналу освітніх організацій. Актуальні проблеми психології : зб. наук. пращь Ін-ту психології імені Г.С. Костюка НАПН України. 2020. Том І. Організаційна психологія. Економічна психологія. Соціальна психологія. Випуск 57. С. 22- 31.

10. Кузнецова А.А., Никишина В.Б. Менеджмент высшей школы: самоэффективность и удовлетворенность профессиональной деятельностью преподавателей высшей школы административного сектора. Иннов: электронный научный журнал. 2018. № 4(37). URL: http://www.innov.ru/science/economy/menedzhment-vysshey-shkoly-samoeffe/

11. Креденцер О.В., Абдуллаєва І.Б. Дослідження особистісних чинників самоефективностіпідприємців сфери торгівлі. Психологічні особливості розвитку організаційної культури в системі державної 
служби, освіти, промисловості та бізнесу : тези IX Міжнарод. конф. з організаційної та економічної психології (30-31 травня 2013 року, м. Київ) / за наук. ред. С.Д. Максименка, Л.М. Карамушки. Київ.-Алчевськ : ДонДТУ, 2013. С. 90-91.

12. Креденцер О. Підприємницька самоефективність персоналу освітніх організацій як чинник розвитку їх підприємницької активності. Організаційна психологія. Економічна психологія. 2016. № 1(4). С. 51-60.

13. Казакова С.В. Особливості самоефективності керівників закладів професійно-технічної освіти як психологічного чинника успішності їхньої професійної діяльності. Вісник післядипломної освіти. Серія: Сочіальні та поведінкові науки. 2018. № 6. С. 65-77.

14. Михайличенко В.С., Полякова Н.В. Роль самоефективності в процесі активізації лідерського потенціалу особистості. Проблеми інженерно-педагогічної освіти. 2014. № 45. С. 179-184. http://nbuv.gov.ua/UJRN/Pipo_2014_45_29

15. Музика О.О. Самоефективність як фактор професіоналізачї студентів. Освітологічний дискурс. 2018. № 3-4 (22-23). С. 83-94.

16. Пророк Н.В. Самоефективність і успішність професійної діяльності. Актуальні проблеми психологї. Т. 7. Вип. 22. К. : Інститут психології імені Г. С. Костюка НАПН України. С. 176-180.

17. Сняданко I.I. Дослідження рівня навчально-професійної самоефективності в студентів технічних університетів. Практична психологія та соціальна робота. 2014. № 4. С. 7-12.

18. Титаренко Т.М. Психологічне здоров'я особистості: засоби самодопомоги в умовах тривалої травматизації : монографія. Національна академія педагогічних наук України, Інститут соціальної та політичної психології. Кропивницький : Імекс-ЛТД, 2018. 160 с.

19. Шапошнік Д.О. Ресурси теорії самоефективності особистості у сучасній психології. Вісник Харківського національного університету. Серія : Психологія. 2011. № 937. С. 302-305.

20. Bandura A. Self-efficacy: The exercise of control. New York : Freeman, 1997. 604 p.

21. Barni D., Danioni F., Benevene P. Teachers' Self-Efficacy: The Role of Personal Values and Motivations for Teaching. Front. Psychol. 2019. № 10. P. 16-45. DOI: 10.3389/fpsyg.2019.01645

22. Guarnaccia C., Scrima F., Civilleri A., Salerno L. The Role of Occupational Self-Efficacy in Mediating the Effect of Job Insecurity on Work Engagement, Satisfaction and General Health. Current Psychology. 2018. № 37. DOI: $10.1007 / \mathrm{s} 12144-016-9525-0$

23. Gumbau R., Peiro J., Salanova M. Moderator effects of self-efficacy on occupational stress. Psychology in Spain. 2001. № 5. P. 63-74.

24. Fabio A., Palazzeschi L. Emotional intelligence and self-efficacy in a sample of Italian high school teachers. Social Behavior and Personality: An international journal. 2008. № 36(3). P. 315-326. DOI: https:// doi.org/10.2224/sbp.2008.36.3.315

25. Judge T.A., Bono J.E. Relationship of core self-evaluations traits-self-esteem, generalized self-efficacy, locus of control, and emotional stability-with job satisfaction and job performance: A meta-analysis. Journal of Applied Psychology. 2001. № 86(1). P. 80-92. DOI: https://doi.org/10.1037/0021-9010.86.1.80

26. Lukat J, Margraf J., Lutz R., van der Veld W. M., Becker E S. Psychometric properties of the Positive Mental Health Scale (PMH-scale). BMC Psychology. 2016. № 4: 8. DOI: 10.1186/s40359-016-0111-x

27. Lent R., Hackett G. Career self-efficacy: Empirical status and future directions. Journal of Vocational Behavior. 1987. №30(3). P. 347-382. DOI: https://doi.org/10.1016/0001-8791(87)90010-8

28. Mo Ching Mok M., Moore P. Teachers \& self-efficacy. Educational Psychology. 2019. № 39:1. P. 1-3. DOI: $10.1080 / 01443410.2019 .1567070$

29. Nauta M.M. Self-Efficacy as a Mediator of the Relationships between Personality Factors and Career Interests.JournalofCareer Assessment.2004.№ 12(4).P.381-394.DOI:https://doi.org/10.1177/1069072704266653

30. Stajkovic A., Luthans F. Self-Efficacy And Work-Related Performance: A Meta-Analysis. Psychological Bulletin. 1998. № 124. P. 240-261. DOI: 10.1037/0033-2909.124.2.240.

31. Schyns B., von Collani G. A new Occupational Self-Efficacy Scale and its relation to personality constructs and organizational variables. European Journal of Work and Organizational Psychology. 2002. № 11. P. 219-241.

\section{REFERENCES}

1. Artemtseva N.H., Halkyna T.V. (2018). Vzaymosviaz mezhdu otnoshenyem k psykholohycheskomu zdoroviu y samootsenkoi lychnosty. Psykholohyia cheloveka kak subekta poznanyia, obshchenyia y deiatelnosty, 457-466 [in Russian].

2. Bondarchuk O.I. (2014). Osoblyvosti orhanizatsiinoi kultury osvitnikh orhanizatsii zalezhno vid samoefektyvnosti kerivnykiv. Aktualni problemy psykholohii, 1(41), 13-19 [in Ukrainian]. 
3. Boiaryntseva A.V. (1995). Motyvatsyonno-kohnytyvnye kharakterystyky lychnosty molodoho predprynymatelia: dys. ... kand. psykhol. Nauk. [in Russian].

4. Vovk O.M. (2010). Samoefektyvnist: sutnist, struktura ta osoblyvosti rozvytku v studentskomu vitsi. Visnyk psykholohii i sotsialnoi pedahohiky : zb. nauk. Prats, 3 [in Ukrainian].

5. Vodopianova N., Husteleva A. (2013). Vosprynymaemaia samoeffektyvnost y resursoobespechennost kak faktore, prepiatstvuiushchye professyonalnomu vyhoranyiu. Vestnyk TvHU. Seryia «Pedahohyka y psykholohyia», 4, 23-30 [in Russian].

6. Haidar M. Y. Razvytye lychnostnoi samoeffektyvnosty studentov-psykholohov na etape vuzovskoho obuchenyia : dyss. ... kand. psykhol. nauk : 19.00.07. Voronezh, 2008. 260 s. [in Russian].

7. Haltseva T.O. (2015). Vydy samoefektyvnosti osobystosti: yikh kharakterystyka ta doslidzhennia. Naukovyi visnyk Khersonskoho derzhavnoho universytetu. Seriia : psykholohichni nauky, 4, 110-114. [in Ukrainian]

8. Hrynberh Dzh. (2002). Upravlenye stressom. [7-e yzd.]. SPb. : Pyter [in Russian].

9. Karamushka L.M., Kredentser O.V., Tereshchenko K.V., Lahodzinska V.I., Kovalchuk O.S., Ivkin V.M. (2020). Empirychne doslidzhennia strukturnykh komponentiv psykholohichnoho zdorovia personalu osvitnikh orhanizatsii. Aktualni problemy psykholohii, Tom I., 57, 22-31 [in Ukrainian].

10. Kuznetsova A.A., Nykyshyna V.B. (2018). Menedzhment vysshei shkoly: samoeffektyvnost y udovletvorennost professyonalnoi deiatelnostiu prepodavatelei vysshei shkoly admynystratyvnoho sektora. Ynnov: эlektronnyi nauchnyi zhurnal. 4(37). URL: http://www.innov.ru/science/economy/menedzhment-vysshey-shkoly-samoeffe/ [in Russian].

11. Kredentser O.V., Abdullaieva I.B. (2013). Doslidzhennia osobystisnykh chynnykiv samoefektyvnosti pidpryiemtsiv sfery torhivli. Psykholohichni osoblyvosti rozvytku orhanizatsiinoi kultury v systemi derzhavnoi sluzhby, osvity, promyslovosti ta biznesu : tezy IX Mizhnarod. konf. z orhanizatsiinoi ta ekonomichnoi psykholohii (30-31 travnia 2013 roku, m. Kyiv) / za nauk. red. S. D. Maksymenka, L. M. Karamushky. Kyiv.-Alchevsk : DonDTU, 90-91 [in Ukrainian].

12. Kredentser O. (2016). Pidpryiemnytska samoefektyvnist personalu osvitnikh orhanizatsii yak chynnyk rozvytku yikh pidpryiemnytskoi aktyvnosti. Orhanizatsiina psykholohiia. Ekonomichna psykholohiia, 1(4), 51-60 [in Ukrainian].

13. Kazakova S.V. (2018). Osoblyvosti samoefektyvnosti kerivnykiv zakladiv profesiino-tekhnichnoi osvity yak psykholohichnoho chynnyka uspishnosti yikhnoi profesiinoi diialnosti. Visnyk pisliadyplomnoi osvity. Seriia: Sotsialni ta povedinkovi nauky, 6. 65-77 [in Ukrainian].

14. Mykhailychenko V.Ie., Poliakova N.V. Rol samoefektyvnosti v protsesi aktyvizatsii liderskoho potentsialu osobystosti. Problemy inzhenerno-pedahohichnoi osvity. 2014. № 45. S. 179-184. http://nbuv.gov.ua/ UJRN/Pipo_2014_45_29 [in Ukrainian].

15. Muzyka O.O. (2018). Samoefektyvnist yak faktor profesionalizatsii studentiv. Osvitolohichnyi dyskurs, 3-4(22-23), 83-94 [in Ukrainian].

16. Prorok N.V. (2010). Samoefektyvnist i uspishnist profesiinoi diialnosti. Aktualni problemy psykholohii. T. 7, 22, 176-180 [in Ukrainian].

17. Sniadanko I.I. (2014). Doslidzhennia rivnia navchalno-profesiinoi samoefektyvnosti v studentiv tekhnichnykh universytetiv. Praktychna psykholohiia ta sotsialna robota, 4, 7-12 [in Ukrainian].

18. Tytarenko T.M. (2018). Psykholohichne zdorovia osobystosti: zasoby samodopomohy v umovakh tryvaloi travmatyzatsii : monohrafiia. Kropyvnytskyi : Imeks-LTD [in Ukrainian].

19. Shaposhnik D.O. (2011). Resursy teorii samoefektyvnosti osobystosti u suchasnii psykholohii. Visnyk Kharkivskoho natsionalnoho universytetu. Seriia : Psykholohiia, 937, 302-305 [in Ukrainian].

20. Bandura A. (1997). Self-efficacy: The exercise of control. New York : Freeman.

21. Barni D., Danioni F., Benevene P. (2019). Teachers' Self-Efficacy: The Role of Personal Values and Motivations for Teaching. Front. Psychol., 10, 16-45. DOI: 10.3389/fpsyg.2019.01645

22. Guarnaccia C., Scrima F., Civilleri A., Salerno L. (2018). The Role of Occupational Self-Efficacy in Mediating the Effect of Job Insecurity on Work Engagement, Satisfaction and General Health. Current Psychology, 37. DOI: $10.1007 / \mathrm{s} 12144-016-9525-0$

23. Gumbau R., Peiro J., Salanova M. (2001). Moderator effects of self-efficacy on occupational stress. Psychology in Spain, 5, 63-74.

24. Fabio A., Palazzeschi L. (2008). Emotional intelligence and self-efficacy in a sample of Italian high school teachers. Social Behavior and Personality: An international journal, 36(3), 315-326. DOI: https://doi. org/10.2224/sbp.2008.36.3.315

25. Judge T.A., Bono J.E. (2001). Relationship of core self-evaluations traits-self-esteem, generalized self-efficacy, locus of control, and emotional stability-with job satisfaction and job performance: A meta-analysis. Journal of Applied Psychology, 86(1), 80-92. DOI: https://doi.org/10.1037/0021-9010.86.1.80 
26. Lukat J, Margraf J., Lutz R., van der Veld W.M., Becker E.S. (2016). Psychometric properties of the Positive Mental Health Scale (PMH-scale). BMC Psychology, 4: 8. DOI: 10.1186/s40359-016-0111-x

27. Lent R., Hackett G. (1987). Career self-efficacy: Empirical status and future directions. Journal of Vocational Behavior, 30(3), 347-382. DOI: https://doi.org/10.1016/0001-8791(87)90010-8

28. Mo Ching Mok M., Moore P. (2019). Teachers \& self-efficacy. Educational Psychology, 39:1, 1-3. DOI: $10.1080 / 01443410.2019 .1567070$

29. Nauta M.M. (2004). Self-Efficacy as a Mediator of the Relationships between Personality Factors and Career Interests. Journal of Career Assessment, 12(4), 381-394. DOI: https://doi.org/10.1177/1069072704266653

30. Stajkovic A., Luthans F. (1998). Self-Efficacy And Work-Related Performance: A Meta-Analysis. Psychological Bulletin, 124, 240-261. DOI: 10.1037/0033-2909.124.2.240

31. Schyns B., von Collani G. (2002). A new Occupational Self-Efficacy Scale and its relation to personality constructs and organizational variables. European Journal of Work and Organizational Psychology, 11, 219-241. 